\title{
Knowledge, Attitude and Practices of Standard Precaution among Nurses in Middle-East Hospital

\author{
Noorasyikin Mohd-Nor ${ }^{\mathrm{a}}$, Yee Bit-Lian ${ }^{\mathrm{a}}{ }^{*}$
} \\ ${ }^{a}$ Cluster of Allied Sciences, Open University Malaysia, Kuala Lumpur, Malaysia.
}

Received 12 August 2019; Accepted 08 November 2019

\begin{abstract}
Introduction: Staff nurses are exposed to many blood and other fluids in the course of their day to day activities in Intensive Care Unit. Purpose of this survey is to assess the level of knowledge, attitudes and practices of standard precaution among nurses in Intensive Care unit, in Middle East Hospital. Method: This was a cross-sectional study and undertaken among nurses by self-administered and anonymous questionnaire that randomly selected in Intensive Care Unit, Middle East Hospital. Results: Female nurses accounted for majority of the respondents which covered $66.7 \%(\mathrm{n}=44)$ while male nurses make up around 33.3\% $(\mathrm{n}=22)$ of the nursing workforce in the study. 53\% $(\mathrm{n}=35)$ of the respondents reported not having any basic exposure or training in infection control practices, while the other $47 \%(\mathrm{n}=31)$ respondents received their training or basic exposure in infection control practices. Majority of the participants had high level of knowledge. Conclusion: In accordance to the self-reported questionnaires, $77 \%(\mathrm{n}=51)$ of the respondents practice good practices of standard precaution. The knowledge, attitude and compliance among ICU nurses in the middle-east hospital towards standard precaution was adequate.
\end{abstract}

Keywords: Standard Precaution; Knowledge; Attitude; Practice; Middle-East Hospital.

\section{Introduction}

Health care professionals are constantly exposed to different types of agent in work place [1-3], many of which can cause serious or even lethal infections $[4,5]$. Nurses in particular are often exposed to various infections during the course of carrying out their nursing activities $[3,6,7]$. Exposure of infectious material can be minimized by adherence to standard precautions, which are designed to reduce the risk of acquiring occupational infection from both known and unexpected sources in the healthcare setting [5, 8, 9]. Nosocomial Infection also known as Health Care Associated Infection (HAI) which is a major cause of mortality in intensive care unit (ICUs), in both developed and developing countries [7, 11, 10]. According to World Health Organization [2] it has been estimated that the risk of healthcare associated infection is 2 to 20 times higher in developing countries compared to developed countries and 5\% and $10 \%$ of patients admitted to hospital in developed countries acquire these infection. Furthermore, the current global effort to reduce healthcare associated infection places strong emphasis on improving compliance to proper hand hygiene techniques and proper usage of personal protective equipment, adherence to standard and transmission based precaution as well as continuing education programs.

Patients in Intensive Care Unit (ICU) are particularly high risk of acquiring nosocomial infections, because of several risk factors [12]. These includes of invasive procedures, inappropriate antibiotic usage, lack of knowledge about infection control practices, overcrowding and high patient ratio to the nurse that are known to contribute to the

\footnotetext{
* Corresponding author: yeebitlian5448@gmail.com

doi http://dx.doi.org/10.28991/SciMedJ-2019-0104-4

$>$ This is an open access article under the CC-BY license (https://creativecommons.org/licenses/by/4.0/).

(C) Authors retain all copyrights.
} 
transfer of pathogenic microorganisms from patient to patient, healthcare workers to patient and vice versa, and also to the environment [12].

Iatrogenic risk factors include invasive procedures (e.g., intubation, indwelling vascular lines, and urine catheterization) and antibiotic use and prophylaxis [12]. Organizational risk factors include such things as contaminated air-conditioning systems, contaminated water systems, staffing (e.g., nurse-to-patient ratio), and physical layout of the facility (e.g., open beds close together). Examples of patient-related risk factors include severity of illness, immunosuppression, and length of stay.

In fact, standard precaution applies to all patients regardless of their diagnosis and designed to reduce the risk of microorganisms from both recognized and unrecognized sources of infection in the hospital [5, 7, 13]. Hand hygiene is the single most important element in standard precaution that required good practices among healthcare workers during care in order to prevent cross transmission of microorganism in patients [14, 7]. This is because enough scientific evidence supports the observation that if properly implemented, hand hygiene alone can significantly reduce the risk of cross-transmission of infection in healthcare facilities [5, 14-16].

\section{Research Background}

Outbreak of multidrug resistant Acinobacter and other organism is the main problem in intensive care unit [12] Acinetobacter baumannii $(A B)$ has emerged as an important pathogen, especially in intensive care units (ICUs).The increasing development of multiple antimicrobial resistances in this pathogen has severely restricted the therapeutic options available for infected patients, and increased the length of stay in ICUs and mortality [12]. Available data regarding therapeutic options for multidrug-resistant Acinetobacter infection are from in vitro, animal, and observational studies as there are no well-designed clinical trials to compare treatment regimens [12].

Point prevalence survey by Ministry of Health (Middle-East) conducted 2 times per year in March and September 2011 shows that Ventilator Associated Pneumonia (VAP) and Catheter Related Blood Stream Infectious (CRBSIs) is the main nosocomial infection which commonly developed in Intensive Care Unit. This kind of infection usually transmitted by healthcare provider through direct contact from one patient to another patient because nurses did not practices the infection control measures, even though they are emphasized to do so.

According to nosocomial data by Infection Control Department, MH Hospital, in Middle-East, which started from January to December 2014, nosocomial infection surveillance data in ICU, rate almost 60 cases was an isolation cases which due to multidrug resistant Acinetobacter species and other organism such as pseudomonas aeuroginosa, candida and gram negative bacilli. This data was collected from January to November 2014 from tracheal aspiration sample, catheter specimens of urine, wound biopsies and blood culture. From all these cases, the truly infected cases were ranging 3-5 cases per month.

When caring for patients, healthcare workers are often required to wear personal protective equipment (PPE) which includes a variety of items such as gloves, gowns, aprons, eye protection, face protection, masks, theatre footwear and caps. The rationale for using protective equipment is to protect both patient and healthcare worker from any potential cross contamination following exposure to microorganisms contained in blood and body fluids [1, 2]. In particular, the Health \& Safety at Work Act (1974) places a duty of care on employers to provide a safe working environment for staff. Further legislation issued by the Health \& Safety Executive in 1992 specified the use of personal protective equipment at work and highlighted the need for employers to take all reasonable steps to ensure appropriate PPE is made available to staff and that it is appropriately used in accordance with training.

Strict adherence to standard precaution guidelines is necessary to prevent exposure to potentially life-threatening infections [3]; however, in spite of the effectiveness of these standard precautions, what reality shows us a very low compliance with this measure by healthcare workers. Medical practitioners, especially nursing department, nurse was high-risk for exposure to blood borne and other infection during direct patient contact if their knowledge, attitude and practices on standard precaution was low. Regular updating and strengthening of infection control practices should be the one of the priority function of any place where health services are rendered [3, 5, 7, 17, 18]. Thus, a right knowledge, a positive attitude and good practices are imperative to guide nurses and other healthcare workers in serving the patients. So this study is important to evaluate the knowledge, attitude and practice of standard precaution among nurses in ICU. In regards, to infection control measures.

\section{Research Methodology}

\subsection{Study Design and Setting}

This was a cross-sectional study and undertaken in ICU, MH Hospital. The total number of beds for nursing department consists of 300 beds in the whole hospital. Total numbers of bed in ICU are 20 beds included of four negative pressure rooms that only used once outbreak occur. Ratio for nurses to patient in Intensive Care Unit is one to one. 


\subsection{Sample and Sampling}

Random sampling technique was use to collect sample from respondents in ICU, MH Hospital. This technique has been chosen because in simple random sampling, every subject has an equal chance of being selected for the study. In this research study, 66 staff nurses were selected as sample size according to Krejcie and Morgan's table (1970).

\subsection{Instrument}

These questionnaires were modified from Internal Policy and Procedures (IPP) Infection Prevention and Control Department-MH Hospital (2011), Centres for Diseases Control and Prevention (CDC), and literature review. The questionnaires consist of four sections.

\subsubsection{Section A: Socio- Demographic Data}

Socio - demographic information consist of five items which is gender, age, year of experience, basic qualification and basic exposure or training in infection control practices.

\subsubsection{Section B: Knowledge Regarding Standard Precaution}

This part consists of 26 questions. It was included of inquiries regarding various components in standard precaution. A correct answer was given score of 1 and 0 for incorrect answer. The scores of knowledge was divided into three groups, which is (Low: 0 - 10, Moderate: 11-20 and High: 21 to 30).

\subsubsection{Section C: Attitude towards Standard Precautions}

These questions are based on attitude of nurses towards standard precaution. There are consists of 15 questions which include both positive and negative. The answers were measured on a 5 Likert scale format with response ranging from Strongly Disagree, Disagree, Undecided, Agree and Strongly Agree. The negative statement was reversed for the purpose of analysis. The attitudes were divided into two groups as positive attitude (good) and negative attitude (bad). The correct answer $9-15$ was considered as positive attitude and $1-8$ was consider as negative attitude).

\subsubsection{Section D: Standard Precaution Practices}

Total of 16 questions were asked regarding practices of standard precaution using answer which consists of Never, Seldom, Sometimes, Often and Very Often.

\subsection{Validity and Reliability}

The content validity of this research study were evaluated by committees made up of experts who was researcher's supervisor and doctors. The experts would ensure that each test covers content that matches all relevant data in the study. To ensure the reliability, the test-retest method was done by given the same test to the same respondents after a period of time. The researcher then distributed the same questionnaires in the next one month's time after the first one. The researcher can refer to the first time the test was given as T1 and the second time that the test is given as T2. The scores on the two occasions are then correlated.

\section{Analysis and Findings}

This study was analysed in lieu of determining the level of knowledge, attitude and practice of standard precaution in ICU of MH Hospital.

\subsection{The Sociodemographic Data or Background Information of Respondents}

As shown in the Table 1, out of 66 nurses, female nurses accounted for majority of the respondents which covered $66.7 \%(\mathrm{n}=44)$ of the nursing workforce in the study. 53\% $(\mathrm{n}=35)$ respondents were in the age group of 22-29 years, and $5 \%(n=3)$ respondents were in the age group of more than 40 years old. In terms of years of experience, $69.7 \%(n$ $=46$ ) respondents have more than 6 years of experience. Regardless the years of experience, majority of respondents depicts to have diploma which indicate of $63.6 \%(n=42)$ and $53 \%(n=35)$ of the respondents reported not having any basic exposure or training in infection control practices. 
Table 1. Background information of respondents $(n=66)$

\begin{tabular}{|c|c|c|}
\hline \multirow{2}{*}{ Variable } & Description & Frequency \\
\hline & \multicolumn{2}{|c|}{$\mathbf{N}(\%)$} \\
\hline \multirow{2}{*}{ Gender } & Male & $22(33.3)$ \\
\hline & Female & $44(66.7)$ \\
\hline \multirow{4}{*}{ Age } & $22-29$ & $35(53)$ \\
\hline & $30-34$ & $18(27)$ \\
\hline & $35-40$ & $10(15)$ \\
\hline & $>40$ & $3(5)$ \\
\hline \multirow{4}{*}{ Years of experiences } & $<2$ years & - \\
\hline & $2-4$ years & $5(7.6)$ \\
\hline & 4-6 years & $15(22.7)$ \\
\hline & $>6$ years & $46(69.7)$ \\
\hline \multirow{3}{*}{ Basic qualification in nursing } & Certificate & - \\
\hline & Diploma & $42(63.6)$ \\
\hline & Degree & $24(36.4)$ \\
\hline \multirow{2}{*}{ Basic exposure/training in infection control practices } & Yes & $31(47)$ \\
\hline & No & $35(53)$ \\
\hline
\end{tabular}

\subsection{Level of Knowledge on Standard Precautions}

Majority of the participants had high level of knowledge as displayed in Table 2. Degree of knowledge was ascertained by means of Yes and No questions on each item which being evaluated. As a result, there were four questions which is number 5, 15, 17 and 20 acquired low scores of correct answers from respondents. One of the knowledge area deprived was about the use of alcohol-based rubs after removing powdered gloves. Scores of correct answers for this question number 5 was $45.1 \%(\mathrm{n}=30)$. There was a problem among respondents in wearing gowns and gloves in situation where contact precaution is required. Scores of correct answers for this question number 15 was $32.6 \%(\mathrm{n}=22)$. Poor performance among respondents was found for the question number 17 regarding stationary, telephones kept in wards and door knobs are not sources of infections. Only $34 \%(n=24)$ of answers were correct. Question number 20 tackled about proper wastage of used ampoules and injections which must not be discarded at clinical waste bin, only $33.3 \%(n=22)$ of total respondents obtained correct answers.

Table 2. Level of Knowledge of Standard Precaution

\begin{tabular}{|c|c|c|c|}
\hline No. & Items & Description & Frequency $\mathbf{N}(\%)$ \\
\hline 1. & $\begin{array}{l}\text { Standard precaution are used for the care of all patients regardless of their diagnosis and perceived } \\
\text { infection status. }\end{array}$ & $\begin{array}{l}\text { Yes } \\
\text { No }\end{array}$ & $\begin{array}{l}65(97.9) \\
1(2.1)\end{array}$ \\
\hline 2. & HIV, Hepatitis B and C could spread through touch. & $\begin{array}{l}\text { Yes } \\
\text { No }\end{array}$ & $\begin{array}{l}24(37) \\
42(63)\end{array}$ \\
\hline 3. & Isolation precaution is one of elements in standard precaution. & $\begin{array}{l}\text { Yes } \\
\text { No }\end{array}$ & $\begin{array}{l}54(81.9) \\
12(18.1)\end{array}$ \\
\hline 4. & Washing hand after contact with the patient's environment is one of 5 movement hand hygiene element. & $\begin{array}{l}\text { Yes } \\
\text { No }\end{array}$ & $\begin{array}{l}63(95.1) \\
3(4.9)\end{array}$ \\
\hline 5. & Alcohol - based rubs be used after removing powdered gloves. & $\begin{array}{l}\text { Yes } \\
\text { No }\end{array}$ & $\begin{array}{l}30(45.1) \\
36(54.9)\end{array}$ \\
\hline 6. & Hand hygiene is required before and after patient care. & $\begin{array}{l}\text { Yes } \\
\text { No }\end{array}$ & $\begin{array}{l}62(93.8) \\
4(6.3)\end{array}$ \\
\hline 7. & $\begin{array}{l}\text { Hands should be washed with soap and water before and after handling potentially infectious materials } \\
\text { irrespective of wearing gloves. }\end{array}$ & $\begin{array}{l}\text { Yes } \\
\text { No }\end{array}$ & $\begin{array}{l}58(87.5) \\
8(12.5)\end{array}$ \\
\hline 8. & $\begin{array}{l}\text { Personal Protective Equipment (PPE) are important in infection control because its cover stains on } \\
\text { clothing. }\end{array}$ & $\begin{array}{l}\text { Yes } \\
\text { No }\end{array}$ & $\begin{array}{l}61(91.7) \\
5(8.3)\end{array}$ \\
\hline 9. & Gloves should be worn every time during handling potentially infectious materials. & $\begin{array}{l}\text { Yes } \\
\text { No }\end{array}$ & $66(100)$ \\
\hline 10. & $\begin{array}{l}\text { Gloves should be changed during patient care if you move hands from 'contaminated body site' to 'clean } \\
\text { body site'. }\end{array}$ & $\begin{array}{l}\text { Yes } \\
\text { No }\end{array}$ & $\begin{array}{l}61(91.7) \\
5(8.3)\end{array}$ \\
\hline 11. & $\begin{array}{l}\text { Surgical mask are using to protect the nose and mouth when procedures and activities are likely to } \\
\text { generate splashes or sprays of blood and body fluids. }\end{array}$ & $\begin{array}{l}\text { Yes } \\
\text { No }\end{array}$ & $\begin{array}{l}57(86.8) \\
9(13.2)\end{array}$ \\
\hline 12. & $\begin{array}{l}\text { Respirator with N95 is required to be worn during the performances of aerosol-generating procedures } \\
\text { such as intubation, and suctioning for patient with influenza A H1N1. }\end{array}$ & $\begin{array}{l}\text { Yes } \\
\text { No }\end{array}$ & $\begin{array}{l}60(91) \\
6(9)\end{array}$ \\
\hline 13. & Goggles should be worn when needed to avoid exposure to eyes. & $\begin{array}{l}\text { Yes } \\
\text { No }\end{array}$ & $66(100)$ \\
\hline 14. & $\begin{array}{l}\text { The purpose of using gown or apron is to protect clothes from splashes or sprays of blood and body } \\
\text { fluids. }\end{array}$ & $\begin{array}{l}\text { Yes } \\
\text { No }\end{array}$ & $\begin{array}{l}65(98.6) \\
1(1.4)\end{array}$ \\
\hline 15. & Do not wear gown and gloves in situation where contact precaution is required. & $\begin{array}{l}\text { Yes } \\
\text { No }\end{array}$ & $\begin{array}{l}22(32.6) \\
44(67.4)\end{array}$ \\
\hline 16. & Removed all personal protective equipment (PPE) before leaving patient's environment. & $\begin{array}{l}\text { Yes } \\
\text { No }\end{array}$ & $\begin{array}{l}59(89.6 \\
7(10.4)\end{array}$ \\
\hline
\end{tabular}




\begin{tabular}{|c|c|c|c|}
\hline 17. & Stationary, telephones kept in wards and door knobs are not sources of infections. & $\begin{array}{l}\text { Yes } \\
\text { No }\end{array}$ & $\begin{array}{l}24(34) \\
42(66)\end{array}$ \\
\hline 18. & $\begin{array}{l}\text { All linen from infectious patient should be thrown in red linen bag although its free from blood and body } \\
\text { fluid. }\end{array}$ & $\begin{array}{l}\text { Yes } \\
\text { No }\end{array}$ & $\begin{array}{l}57(86.8) \\
9(13.2)\end{array}$ \\
\hline 19. & Segregation of waste (clinical or non-clinical) is important for preventing spread of infection. & $\begin{array}{l}\text { Yes } \\
\text { No }\end{array}$ & $\begin{array}{l}62(94.4) \\
4(5.6)\end{array}$ \\
\hline 20. & Ampoules injection that has been used must throw at clinical waste bin. & $\begin{array}{l}\text { Yes } \\
\text { No }\end{array}$ & $\begin{array}{l}22(33.3) \\
44(66.7)\end{array}$ \\
\hline 21. & IV Line should not be manipulated before discarded at clinical waste bin. & $\begin{array}{l}\text { Yes } \\
\text { No }\end{array}$ & $\begin{array}{l}47(71.5) \\
19(28.5)\end{array}$ \\
\hline 22. & Unfinished IV solution should be thrown in sluice room before discarded in clinical waste bin. & $\begin{array}{l}\text { Yes } \\
\text { No }\end{array}$ & $\begin{array}{l}39(59) \\
27(41)\end{array}$ \\
\hline 23. & Used needle should never be bent or recapped. & $\begin{array}{l}\text { Yes } \\
\text { No }\end{array}$ & $\begin{array}{l}56(85) \\
10(15)\end{array}$ \\
\hline 24. & $\begin{array}{l}\text { If you puncture hand with sharp instruments, immediately wash dry hands and report to the concerned } \\
\text { authorities. }\end{array}$ & $\begin{array}{l}\text { Yes } \\
\text { No }\end{array}$ & $\begin{array}{l}57(81.6) \\
9(13.9)\end{array}$ \\
\hline 25. & Puncture-proof containers should be used for disposal of sharps. & $\begin{array}{l}\text { Yes } \\
\text { No }\end{array}$ & $66(100)$ \\
\hline 26. & $\begin{array}{l}\text { Placed mask on coughing patients to potential dissemination of infectious respiratory secretions from the } \\
\text { patient to others. }\end{array}$ & $\begin{array}{l}\text { Yes } \\
\text { No }\end{array}$ & $\begin{array}{l}65(97.9) \\
1(2.1)\end{array}$ \\
\hline
\end{tabular}

\subsection{Attitude towards Standard Precautions}

Majority of the respondents $70 \%(n=46)$ had positive attitude towards standard precautions compare to neutral attitude $30 \%(\mathrm{n}=20)$ as shown in Table 3. Opinions obtained from the respondents regarding standard precaution included the purpose of standard precaution, hand hygiene, use of personnel protective equipment (PPE) in differences circumstances, environmental cleaning and waste disposal.

The principle of standard precaution was positively adapted in daily events in Critical Care Unit, MH Hospital. Majority of the respondents had positive attitude towards standard precaution as showed in question number 1, which is $43.1 \%(\mathrm{n}=28)$ of the respondents "disagree" that standard precaution is not easy to follow. For question number 15 , $59.7 \% 9(\mathrm{n}=39)$ of the respondents "agreed" that it is not logic to assume all patients contagious unless their infection has been confirmed. These results indicate that some of the respondents were not optimistic towards standard precaution. The Figure 2 shows the percentage of the respondent's attitude towards complying of standard precaution.

Table 3. Attitude towards Standard Precaution

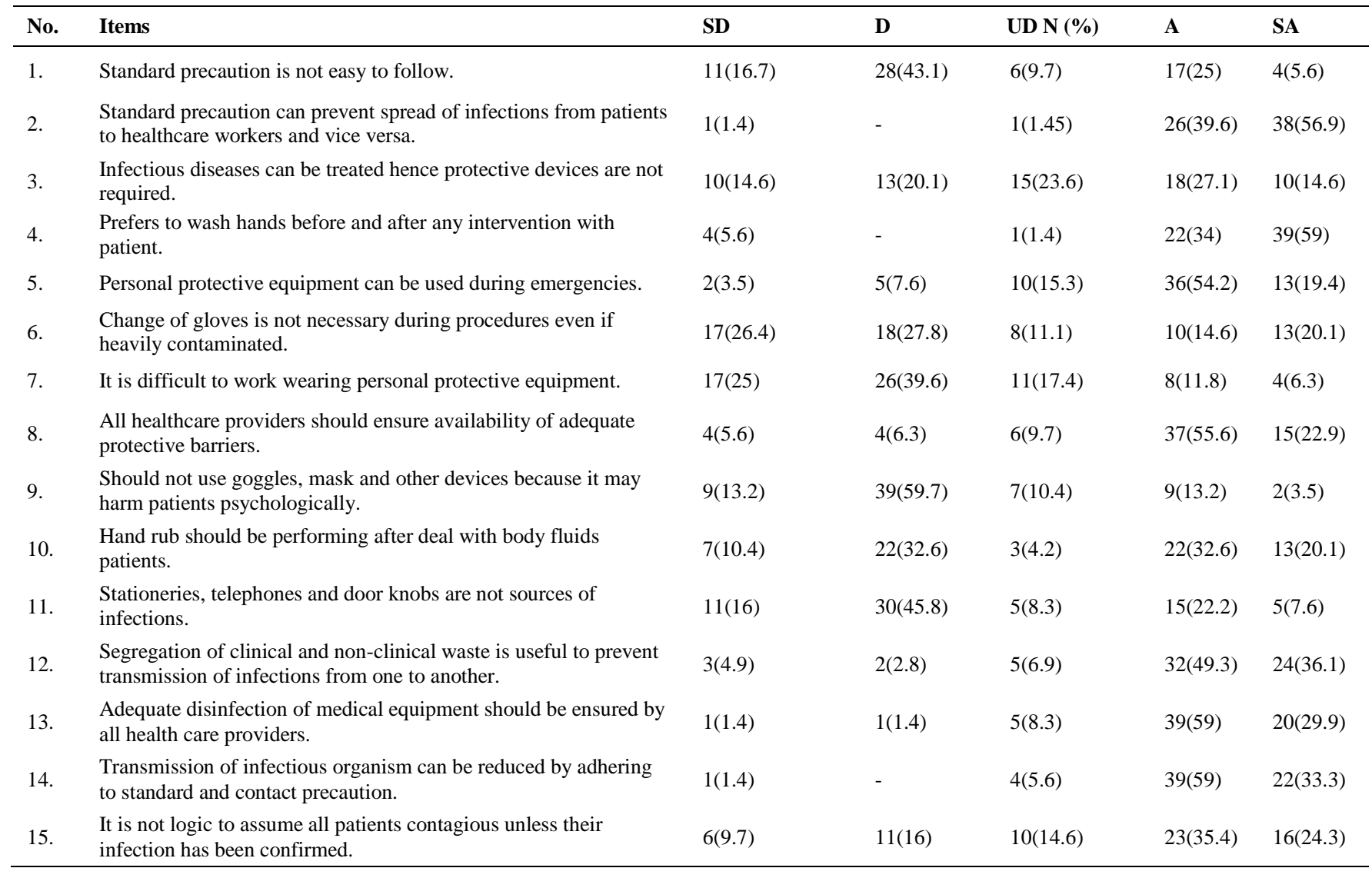




\subsection{Standard Precaution Practices}

In accordance to the self-reported questionnaires, $77 \%(\mathrm{n}=51)$ of the respondents practice good practices of standard precaution while $23 \%(\mathrm{n}=15)$ of the respondents were in moderate level when practicing standard precaution. As mention above, majority of the respondent's practices good standard precaution in a specific situations as showed in the Table 4. Nevertheless there are several questions tackled the lack of practices of standard precaution which is in questions number 9 and 13 .

Question number 9 showed that $41.7 \%(\mathrm{n}=27)$ of the respondents choose 'sometimes', $23.6 \%(\mathrm{n}=16)$ choose 'seldom' and 6.3\% ( $\mathrm{n}=4)$ choose 'never' in situations where they were asked to wears gloves when performing parenteral injection of medications. For questions number 13, 25.8\% ( $\mathrm{n}=17)$ of the respondents choose 'sometimes', $35.4 \%(n=24)$ choose 'seldom', and $2.8 \%(n=2)$ in situations when they were asked to wears protective eye patch or goggle when performing operations/procedures that might induce spraying of blood, body fluid, secretions and excretions.

For questions number $16,75.8 \%(n=50)$ of the respondents choose 'very often' and $24.2 \%(n=16)$ choose 'often' in situation when they were asked to dispose needles and blades in a sharp disposal box or receptacle after using. This percentage and frequency shows that all of the respondents agreed to do the same when the situation comes.

Table 4. Standard Precaution Practices

\begin{tabular}{|c|c|c|c|c|c|c|}
\hline No. & Items & Never & Seldom & Sometimes N (\%) & Often & Very Often \\
\hline 1. & Washes hands when comes in contact with different patients. & - & $1(1.4)$ & $1(1.4)$ & $33(50)$ & $31(47.2)$ \\
\hline 2. & Washes hands after taking off the gloves. & - & $1(1.4)$ & $9(13.2)$ & $35(52.8)$ & $21(31.9)$ \\
\hline 3. & $\begin{array}{l}\text { Washes hands immediately after contacting any blood, body fluid, } \\
\text { secretion, excretion and dirty substances. }\end{array}$ & - & - & $4(5.6)$ & $34(51.4)$ & $28(41.7)$ \\
\hline 4. & Wears gloves when drawing blood samples. & $2(3.5)$ & $14(20.8)$ & $11(16)$ & $24(36.8)$ & $15(22.9)$ \\
\hline 5. & Wears gloves when disposing stool and urine. & - & $1(1.4)$ & $16(25)$ & $24(36)$ & $25(37.6)$ \\
\hline 6. & Wears gloves when handling impaired patient skin. & $2(2)$ & $2(2)$ & $12(18)$ & $21(33.3)$ & $29(45.1)$ \\
\hline 7. & Wears gloves when handling patient's mucosa. & - & $4(7)$ & $17(25)$ & $22(33.3)$ & $23(35.4)$ \\
\hline 8. & Wears gloves when handling saliva or sputum culture. & - & $2(4.2)$ & $8(11.8)$ & $34(51.4)$ & $22(32.6)$ \\
\hline 9. & Wears gloves when performing parenteral injections of medications. & $4(6.3)$ & $16(23.6)$ & $27(41.7)$ & $13(19.4)$ & $6(9)$ \\
\hline 10. & Wears gloves when dressing wounds. & - & - & $7(10)$ & $12(18.5)$ & $47(71.5)$ \\
\hline 11. & Wears gloves when comes in contact with blood. & - & $3(4)$ & $7(11)$ & $12(17.6)$ & $44(67.4)$ \\
\hline 12. & $\begin{array}{l}\text { Wears mask when performing operations/ procedures that might } \\
\text { induce spraying of blood, body fluid, secretions and excretions. }\end{array}$ & - & $2(2.8)$ & $14(21.8)$ & $23(34.7)$ & $27(40.7)$ \\
\hline 13. & $\begin{array}{l}\text { Wears protective eye patch or goggle when performing } \\
\text { operations/procedures that might induce spraying of blood, body } \\
\text { fluid, secretions and excretions. }\end{array}$ & $2(2.8)$ & $24(35.4)$ & $17(25.8)$ & $20(30.9)$ & $3(5.1)$ \\
\hline 14. & $\begin{array}{l}\text { Wears protective suits or gown when performing } \\
\text { operations/procedures that might induce spraying of blood, body } \\
\text { fluid, secretions and excretions. }\end{array}$ & - & $1(0.7)$ & $4(6.3)$ & $31(47.2)$ & $30(45.8)$ \\
\hline 15. & Not recap syringe after using. & - & $1(0.7)$ & $4(5.6)$ & $20(31.3)$ & $41(62.5)$ \\
\hline 16. & $\begin{array}{l}\text { Dispose needles and blades in a sharp disposal box or receptacle } \\
\text { after using. }\end{array}$ & - & - & - & $16(24.2)$ & $50(75.8)$ \\
\hline
\end{tabular}

\section{Discussion}

The primary goal of the present study was to assess the knowledge, attitude and practices of standard precaution among nurses in ICU of MH Hospital. Studies have reported different levels of knowledge, attitude and practices related to standard precaution among nurses [5, 7, 13, 18-22].

Findings of this study indicated that $69.7 \%$ of participants had a high knowledge concerning standard precaution. This is probably due to respondent's years of experience. All respondents have more than two years of experience in nursing background. Most of the respondents have more than six years of experience. The more years of experience they have, the more knowledgeable they are. In addition, almost half of the respondents, which are $47 \%$ of respondents, have basic exposure/ training in infection control practices which contribute to be an extra knowledge compared to others. However, the study done by Labrague et al. [19], reported that the vast majority, 89.7\% of participants had good knowledge about standard precaution. Moreover, provision of information about healthcareassociated infections will influence knowledge and behaviors because nurses will be able to answer correctly and will appropriately use infection control measures when they received information from educational courses and scientific journals [23]. This shows that by providing nurses with appropriate information of standard precaution will help 
nurses to understand more so that they can have good quality of practice of standard precaution in their daily events or routine $[23,24]$.

This study also revealed the level of knowledge on standard precaution and application of standard precaution among nurses in Intensive Care unit, MH Hospital when dealing with the patient. 97.9\% of participants knew that standard precaution measures should be applied to all patients regardless of their diagnosis and perceived infection status. It is similar to the previous study which showed that $84.5 \%$ of participants knew that standard precaution should be applied to all patients [19]. Application of standard precaution regardless of patient's diagnosis or infection status will help nurses in order to protect themselves from any unintentional problem in the future [25]. In contrary, Khalooei and Kahlooei reported that compliance with standard precautions was not favourable among nurses in Iran [23], and suggested for managerial and educational interventions [3, 23, 24].

The level of knowledge regarding hand washing showed that the vast majority of participants, which is $87.5 \%$, agreed that hands should be washed with soap and water before and after handling potentially infectious materials irrespective of wearing gloves. It is similar to the studies done in Iran which shows that $97.9 \%$ of participants were aware that hand washing is important method of controlling the spread of infection [20]. Pertaining to the level of knowledge on hand washing when dealing with patients, 93.8\% of respondents knew that hands should be washed before and after contact with patients. However, in contrast, study by Abou El-enein and El-Mahdy found that only $47.1 \%$ of participants knew that hands should be washed before and after caring of patients [21]. In a study about hand hygiene among health care staff; notes that nurses' knowledge about standard precautions is not enough and many of them believed that by wearing gloves there is no need for washing hands [15]. In addition, Stein et al. found that the most common reasons specified for not washing hands before and after patient contact were time constraint, including emergency situations [22].

As we know, hand washing is the single most important elements in standard precaution [2]. Accordance to WHO, five elements of hand hygiene should be follow in order to prevent any cross infection or spread of microorganism. The five moments of hand hygiene as recommended are, before touching a patient, before clean / doing any aseptic procedure, after body fluid exposure risk, after touching patient and after touching patient's surrounding. Hand washing should be done in all circumstances when hands visibly soiled and hand rub are advisable to be done when hands not visibly soiled because it will not be effective when hands are visibly soiled or greasy [2].

This study also shows that respondents have high level of knowledge when they were asked to wear gloves every time during handling potentially infectious materials which is $100 \%$ and they also aware the need for changing gloves during patient care if moving hands from "contaminated body site" to clean body site" which is $91.7 \%$. This was differing from the study conducted by [26] on hand decontamination practices and the appropriate use of gloves in two intensive care units in Malaysia. Accordingly, results showed that although the compliance rate of hand hygiene practices was at acceptable percentage of $70 \%$ before each patient contact, unfortunately, the respondents did not completely adhere to the hand washing steps. The average time taken to wash hands was 20 seconds and hand washing protocol was generally followed by all respondents (100\%), while only $4 \%$ of respondents changed contaminated gloves between patients.

Standard precautions apply to blood; all body fluids, secretions, and excretions (except sweat); non-intact skin; and mucous membranes [1, 9]. From the studies, regarding compliance of participants to PPE (mask, gowns and goggles), the results shows that $86.8 \%$ of respondents always wore masks when procedures and activities were likely to generate splashes or sprays of blood or body fluids, while $98.6 \%$ of them wearing gowns or aprons to protect clothes from splashes or sprays of blood and body fluids. On the other hand, all respondents agreed that goggles should be worn when needed to avoid exposure to eyes. Our results resemblance to the study conducted by Taze and Cavdar [9] with mean of $55.19(\mathrm{SD}=10.7)$.

Another fact of this study related to the knowledge on proper handling of needles and sharps. This is contradictory to the study of Labrague et al. [19], which reported that $82.8 \%$ of participants threw the used needle and sharp object into sharp containers immediately. However, in this study shows that $85 \%$ of respondents knew that used needles should never be bent or recapped before discarded in the sharp bin. It is similar to the studies done Almurr [25] which shows most respondents $(81 \%)$ knew that used needle should not be recapped after use. This might be due to the fact that $53 \%$ of the respondents in this study received training in infection control practices. Other reasons that researcher perceived are, more exposure and guidelines given in dealing with the needles, respondents have awareness of the risk of needle stick injuries that may results from recapping the needle and possibility of transmission of blood-borne pathogen.

Another key finding from our study was that the attitudes towards standard precaution were encouraging, since $70 \%$ of respondents reported to have positive attitude. In particular, $56.9 \%(\mathrm{n}=38)$ "strongly agreed" and $39.6 \%$ "agreed" with following statement which standard precaution can prevent spread of infection from patient to healthcare workers and vice versa. Statement of "It is not logic to assume all patients contagious unless their infection 
has been confirmed" shows that respondents have positive attitude towards standard precaution when $24.3 \%$ of respondents "strongly agreed" and $35.4 \%$ of respondents "agree" to this statement. The "standard precautions," which are devised to be used for the care of all patients in hospitals regardless of their diagnosis or presumed infection status, now replace the "universal precautions." Standard precautions are the underpinning principles for routine safe practices $[1,2]$. They are precautions that should be practiced by all clinical staff without exception, to limit the risk of potentially harmful organisms being transmitted to the patient, healthcare worker, visitor or the environment [1, 2]. Opinions obtained from the respondents regarding standard precaution including the purpose and important of standard precaution, hand hygiene, use of personnel protective equipment (PPE) in different situations or circumstances, environmental cleaning and waste disposal. The principle of standard precaution was positively adapted in daily practices in Intensive Care Unit, MH Hospital.

Knowledge affects attitude and it is required to initiate the process that culminated in attitude. Thus, provision of education and training courses on standard precautions to healthcare providers could be consider as important in order to ensure the continuity of good practice in standard precaution [23, 24]. This study found that respondents who had higher scores of knowledge more likely to obtained higher scores of practices and those with correct attitude also more likely to have correct practices. These findings seem to be consistent with previous research done by Askarian et al. [20], which found attitude and knowledge is important factors that affect practices. Separately, factors affecting taking necessary precautions were due to lack of equipment $(61.6 \%)$ and not being able to work at ease (48\%) as reported by Taze and Cavdar [9]. On the other hand, cases of poor-compliance modelling by nursing students reported that they were having difficulties in adhering to standard precautions when they were partnered with noncompliant nurses [24].

Level of knowledge may be vary due to different nationality of respondents in Intensive Care unit, MH hospital. The infection control practice also might be different in their back home, but as they are working in the same hospital setting, the standard practice of infection control can be applied and all the respondents may practice the same standard regardless of their nationality.

In our study, $77 \%$ of the respondents represent a good practice towards standard precaution. This means that majority of the respondents were practicing standard precaution, nevertheless $23 \%$ of the respondents were categorized as poor to moderate while practicing standard precaution. In the studies done by Abou El-enein and El Mahdy [21], 52.9\% of the nurses knew that they had to wash their hands after caring for a patient and $70.6 \%$ mentioned that hand hygiene and wearing gloves are indicated to protect health workers, whereas none of them mentioned that hand hygiene is important to protect the patient. This is probably associated with the providers' concern for the possible transmission of pathogenic viruses by patients. In contrast, health workers tend to disregard their own role in transmitting infections to patients. This is in agreement with the study of [19], which showed that nurses and physicians reported a low rate of hand hygiene before direct patient contact and suggested that hand hygiene, is more likely to be performed when self-protection is the goal.

The respondents who displayed poor to moderate practices which are represents by $23 \%$ in this study could be related to several factors for example absence of appropriate training curricula in infection control as well as in standard precautions for nurses in the hospital and medical training facilities. The other factors might be due to lack of appropriate incentives or medical equipment in the hospital.

\section{Acknowledgements}

The authors would like to thank the participants for their willingness to participate in this study. Ethical approval has been granted from the Ethical Approval at the Faculty of Nursing and Allied Health Sciences, Open University Malaysia. We also would like to express our gratitude to the ICU nurses of MH Hospital who spent time to participate in this study, as well as the hospital management for their valuable suggestions and support.

\section{Declaration of Competing Interest}

The authors declare that they have no known competing financial interests or personal relationships that could have appeared to influence the work reported in this paper.

\section{References}

[1] Update: Universal Precautions for Prevention of Transmission of Human Immunodeficiency Virus, Hepatitis B Virus, and Other Bloodborne Pathogens in Health-Care Settings. (1988). AORN Journal, 48(3), 586-596. doi:10.1016/s0001-2092(07)69767-1.

[2] World Health Organization. (2008). The first Global Patient Safety Challenge: "Clean care is safer care", Geneva. Available online: https://www.who.int/gpsc/background/en/ (accessed on 1 May 2019).

[3] Bottaro, B. B., Pereira, F. M. V., Reinato, L. A. F., da Silva Canini, S. R. M., Malaguti-Toffano, S. E., and Gir, E. (2016). Adherence to Standard Precautions by Nursing Professionals: A Literature Review. Journal of Nursing, 10(3), 1137-1142. doi: 10.5205/reuol.8702-76273-4-SM.1003201625 
[4] Twitchell, K. T., \& Wachs, J. E. (2003). Bloodborne Pathogens: What you Need to Know-Part II. AAOHN Journal, 51(2), 8997. doi:10.1177/216507990305100210.

[5] Fashafsheh, I., Ayed, A., Koni, M., Hussein, S., \& Thultheen, I. (2016). Midwives and Nurses Compliance with Standard Precautions in Palestinian Hospitals. Open Journal of Nursing, 06(04), 294-302. doi:10.4236/ojn.2016.64030.

[6] Kosgeroglu, N., Ayranci, U., Vardareli, E., \& Dincer, S. (2004). Occupational exposure to hepatitis infection among Turkish nurses: frequency of needle exposure, sharps Injuries and vaccination. Epidemiology and Infection, 132(1), 27-33. doi:10.1017/s0950268803001407.

[7] Ogoina, D., Pondei, K., Adetunji, B., Chima, G., Isichei, C., \& Gidado, S. (2015). Knowledge, attitude and practice of standard precautions of infection control by hospital workers in two tertiary hospitals in Nigeria. Journal of Infection Prevention, 16(1), 16-22. doi:10.1177/1757177414558957.

[8] Siegal, J.D., Rinchart, E., Jacson, M., Chiarello, L., \& HISPAC. (2007). Guidelines for isolation Precautions: Prevention Transmission of Infection Agents in Health Care Settings, Atlanta: CDC.

[9] Taze, S. S., and Cavdar, I. (2016). Universal Precautions that Surgical Nurses are taken for Preventing from Diseases Trasmitted by blood and Body Fluids in Instanbul. International Jounral of Caring Sciences, 9 (1), 111-121

[10] Siegal, J. D., Rinchart, E., Jacson, M., \& Chiarello, L. (2007). Healthcare Infection Control Practices Advisory Committee, Guideline for isolation precautions: Preventing Transmission of Infectious Agents in Healthcare Settings: Centres for Diseases Control. Available online: http://www.cdc.gov/ncidod/dhqp/pdf/guidelines/Isolation2007.pdf (accessed on 15 May 2019).

[11] Siegel, J. D., Rhinehart, E., Jackson, M., \& Chiarello, L. (2007). 2007 Guideline for Isolation Precautions: Preventing Transmission of Infectious Agents in Health Care Settings. American Journal of Infection Control, 35(10), S65-S164. doi:10.1016/j.ajic.2007.10.007.

[12] Ulu-Kilic, A., Ahmed, S., Alp, E., \& Doğanay, M. (2013). Challenge of intensive care unit-acquired infections and Acinetobacter baumannii in developing countries. OA Critical Care, 1(1). doi:10.13172/2052-9309-1-1-382.

[13] Yassi, A., Lockhart, K., Corps, R., Kerr, M., Corbiere, M., Bryce, E. A.,...Sharon, S. (2007) Determinants of Healthcare Workers' Compliance with Infection Control Procedures. Healthcare Quarterly. 10(1), 44-52. doi: 10.12927/hcq.2007.18648.

[14] Ji, G., Yin, H., \& Chen, Y. (2005). Prevalence of and risk factors for non-compliance with glove utilization and hand hygiene among obstetrics and gynaecology workers in rural China. Journal of Hospital Infection, 59(3), $235-241$. doi:10.1016/j.jhin.2004.09.027.

[15] Malekmakan, L., Haghpanah, S., Askarian, M., Jowkari, M., \& Moalaee, M. (2008). Hand hygiene in Iranian health care workers. American Journal of Infection Control, 36(8), 602-603. doi:10.1016/j.ajic.2008.01.006.

[16] Patil, K., Shetty, S., \& Sawanth, S. (2016). A Descriptive Study to Assess the Knowledge Regarding Nosocomial Infections among the Second Year GNM Students in D. Y. Patil Institute of Nursing Sciences, Kadamwadi, and Kolhapur, Maharashtra. International Journal of Nursing Education, 8(2), 111. doi:10.5958/0974-9357.2016.00058.1.

[17] Mudedla, S., Reddy, K., Sowribala, M., \& Tej, Wl. (2014). A study on knowledge and awareness of standard precautions among health care workers at Nizam' s institute of medical sciences Hyderabad. The Journal of National Accreditation Board for Hospitals \& Healthcare Providers, 1(2), 34. doi:10.4103/2348-6139.151296.

[18] Nazeera, N.T Aneepanichsakul, S. (2008). Knowledge, attitude and practice of standard and transmission-based precautions in tertiary and secondary health care settings of Maldives. Journal Health Resp. 22, 45-48.

[19] Labrague, L., Rosales, R., \& Tizon, M. (2012). Knowledge and Compliance of Standard Precautions among Student Nurses. International Journal of Advanced Nursing Studies, 1(2), 84-97. doi: 10.14419/ijans.v1i2.132.

[20] Askarian, M., Memish, Z., \& Khan, A. (2007).Knowledge, practice and attitude among Iranian nurses, midwives and students regarding standard Isolation Precautions. Infection Control and Hospital Epidemiology, 28 (2), 241-244. doi: 10.1086/510868.

[21] Abou El-Enein, N. Y., \& El Mahdy, H. M. (2011). Standard precautions. Journal of the Egyptian Public Health Association, 86(1\&2), 3-10. doi:10.1097/01.epx.0000395430.92943.69.

[22] Stein, A.D., Makarawo, T.P., \& Ahmad, M.F. (2003). A survey of doctors' and nurses' knowledge, attitudes and compliance with infection control guidelines in Birmingham teaching hospitals. Journal of Hospital Infection, 54 (1), 68-73. doi:10.1016/S0195-6701(03)00074-4.

[23] Khalooei, A., \& Khalooei, S. (2017). Study on primary prevention of blood borne pathogens among nursing staff of teaching hospitals of Kerman University of Medical Sciences. Pars of Jahrom University of Medical Sciences, 15(2), 47-54. doi:10.29252/jmj.15.2.47.

[24] Kim, K. M., \& Oh, H. (2015). Clinical Experiences as Related to Standard Precautions Compliance among Nursing Students: A Focus Group Interview Based on the Theory of Planned Behavior. Asian Nursing Research, 9(2), $109-114$. doi:10.1016/j.anr.2015.01.002. 
[25] Almurr, B.J. (2013). Knowledge and Practice of Standard Precaution and Sharp Injures among Nurses in the Northern West Bank Hospitals; Palestine (Doctoral dissertation, Faculty of Graduate studies, An-Najah National University).

[26] Katherason, S. G., Naing, L., Jaalam, K., Nik Mohamad, N. A., Bhojwani, K., Harussani, N. D. S. H., \& Ismail, A. (2009). Hand decontamination practices and the appropriate use of gloves in two adult intensive care units in Malaysia. The Journal of Infection in Developing Countries, 4(02), 118-123. doi:10.3855/jidc.593. 